\title{
Effects of punica granatum peel extract and/ or sitagliptin on induced diabetic nephropathy in adult male albino rats
}

\author{
Hanan E. Mohamed ${ }^{1}{ }^{*}$, Nadia H. Al-Eryan ${ }^{2}$, Mohamed F.Elsayed ${ }^{1}$, Ghada M. Salah-Eldin ${ }^{2}$ \\ ${ }^{1}$ Physiology Department, Faculty of Medicine, Helwan University, Cairo, Egypt \\ ${ }^{2}$ Physiology Department, Faculty of Medicine for Girl, Cairo, Al-Azhar University, Egypt
}

ABSTRACT

Background: Type 2 diabetes mellitus (T2DM) represents about $90 \%$ of diabetic cases. Diabetic nephropathy (DN) is one of the most serious complications of diabetes. Sitagliptin has an important role in enhancement of the Glucagon-like peptide receptor (GLP-1R) which present in the kidneys, so it may have a role in enhancement of the kidney function in T2DM. Also, Punica granatum peels extract (PGPE) is a herb which has anti-hyperglycemic and antioxidant activities.

Objective: This study was designed to investigate the role of PGPE and/or sitagliptin on renal functions in induced diabetes.

Methodology: The current study was performed on 60 adult male albino rats. Rats weighing 200 to 250 grams. Rats were divided into: Group I "normal control animals" consists of 20 rats (divided into group 1: normal control and group 2: vehicle received control) 10 rats / each. Group II "Diabetic animals" consist of 40 rats were divided into 4 treated groups: (Diabetic, PGPE, Sitagliptin, sitagliptin and PGPE) 10 rats /each. At the end of experimental period (6 weeks), urinary protein, fasting blood glucose (FBG), urea, blood urea nitrogen (BUN), creatinine, malonyldialdehyde (MDA), tumor necrosis factor alpha (TNF $\alpha$ ), antioxidant enzymes and histopathology of renal tissue were assayed.

Results: In diabetic rats there were increased FBG, urea, BUN, creatinine, urinary protein, MDA and TNF $\alpha$ with decreased GSH and SOD. Treatment with PGPE and sitagliptin caused decrease in SFBG, urea, BUN, creatinine, TNF $\alpha$, MDA and total protein with increase in GSH and SOD.

Histopathological examination of diabetic rats revealed dilated glomerular space and dilated degenerated tubules. Treatment with PGPE and sitagliptin revealed improvement in the glomerular space with less tubular dilatation.

Conclusion: Results of the present work showed that combination of PGPE and sitagliptin have synergistic effects for each other and have a better renoprotective effects in diabetic rats.

JRAM 2020; 1 (2):104-115

Keywords: Antioxidants; flavonoids; nephroprotective; nicotinamide; streptozotocin.

Submission date: 21 January 2020

Acceptance date: 1 March 2020

Corresponding author: Hanan Essam Mohamed, Department of physiology, Faculty of medicine- Helwan University, Egypt, Tel: 01274804838, E-mail: hanan.essam@med.helwan.edu.eg

Please cite this article: Mohamed ME, Al-Eryan NH, Elsayed MF, Salah Eldin GMM. Effects of punica granatum peel extract and/ or sitagliptin on induced diabetic nephropathy in adult male albino rats. JRAM 2020; 1 (2): 104-115.

DOI:10.21608/jram.2020.22457.1035

\section{INTRODUCTION}

T2DM represents about $90 \%$ of all diabetic cases. There is insulin resistance in T2DM [Error! Reference source not found.]. Glucose control can lower the threat of diabetic complications [Error! Reference source not found.]. Diabetic nephropathy (DN) represents a serious longterm complication of DM [Error! Reference source not found.]. It is the major cause of end stage renal disease, accounts about $30-35 \%$ incidents of renal alternative therapy globally [Error! Reference source not found.].
Hyperglycemia leads to glomerular hyper filtration; micro albuminuria and eventually end stage renal disease ${ }^{[5]}$. Hyperglycemia is also known to develop oxidative stress so it's involved in the generation of reactive oxygen species (ROS) which play an important role in the pathogenesis of DN ${ }^{[6] .}$ GLP-1R is present in the kidneys, so it has a role in the modulation of kidney function ${ }^{[7] .}$ Activation of GLP$1 \mathrm{R}$ attenuates diabetic renal injury by reduction of kidney inflammation and oxidative stress ${ }^{[8]}$. 
Sitagliptin is an oral antidiabetic drug, its main goals is to prolong the effects of endogenous GLP-1 by inhibiting the activity of Dipeptidyl peptidase-IV (DPP-IV) enzyme [9]. PGPE is a herb which is important for treatment of diabetes ${ }^{[10]}$. The study of Patil et al. ${ }^{[11]}$ proved the antihyperglycemic and antioxidant activities of PGPE, due to presence of flavonoids such as ellagitannins, gallic acid and anthocyanins ${ }^{[12]}$.

\section{MATERIAL AND METHODS}

The present study was carried out at the animal house, Physiology department faculty of medicine for girls, Al-Azhar University.

Experimental drugs: Streptozotocin, nicotinamide and sitagliptin

Sitagliptin: Drug was provided in the form of tablets (50 mg/tablet) and given to the rats in a dose of (10 $\mathrm{mg} / \mathrm{kg} /$ day) orally via a gastric gavage ${ }^{[13]}$.

\section{Experimental methodology:}

Induction of T2DM: Rats were fasted all over the night then, they had been injected by a nicotinamide dissolved in normal saline $(110 \mathrm{mg} / \mathrm{kg})$ i.p then after $15 \mathrm{~min}$ rats were injected i.p by a streptozotocin $(45$ $\mathrm{mg} / \mathrm{kg}$ ) dissolved in citrate buffer of $\mathrm{pH} 4.5$. Hyperglycemia was verified via increased blood glucose levels after 72 hours and then on $7^{\text {th }}$ days. Those animals with fasting blood glucose greater than $250 \mathrm{mg} / \mathrm{dL}$ \& raised creatinine level were used for DN study ${ }^{[14-15] \text {. }}$

Experimental plant material: Fruits was cut into portions. Then, the peels were cut into small pieces and leave to be dried until complete dehydration. Dried peels were grounded into powder which was stored at $5{ }^{\circ} \mathrm{C}$ till used. It was suspended in warm distilled water $(100 \mathrm{mg} / 1 \mathrm{ml})$ and was given to the rats orally via a gastric gavage in a dose (200 $\mathrm{mg} / \mathrm{kg} /$ day) ${ }^{[16-17]}$.

Experimental design: Rats were divided into 6 equal experimental groups.

Group I (Normal control): Received ordinary rat chow.

Group II (Control citrate buffer): Were injected i.p with sodium citrate buffer pH4.5 (vehicle received).

Group III (Diabetic): T2DM

Group IV (Diabetic plus PGPE): PGPE treated group (started one week after induction of DM) for 6 weeks.

Group V (Diabetic plus sitagliptin): Sitagliptin treated group (started one week after induction of DM) for 6 weeks.

Group VI (Diabetic treated with sitagliptin and PGPE): Received sitagliptin \& PGPE (started one week after induction of DM) for 6 weeks.

Experimental protocol: At the end of the experimental period, rats were put in a metabolic cage for 24 hours to collect urine samples to detect total protein level (It has a feeder chamber located outside the cage that contains a feeder drawer that slides out for easy filling. This set-up prevents the urine from getting contaminated with the food. The cages have a water bottle support and spillage collection tube designed to prevent water from entering the cage and contaminating the urine). Then rats were fasted for 12 hours, blood samples were taken from retro-orbital plexus using heparinized capillary tubes under light ether anesthesia. It was introduced at the inner canthus of the eye and advanced gently along the sides of the globe into the venous plexus. The serum was prepared according to ${ }^{[18]} \&$ used for estimation of: Fasting serum Glucose (FSBG), urea, blood urea nitrogen (BUN) and creatinine.

Tissue samples: after sample collection, rats were sacrificed by cervical dislocation. Kidneys were excised, left kidney of each rat was rapidly dissected and washed with saline and fixed in $10 \%$ formalin for histopathological examination. Tissue homogenate of the right kidney: the supernatant was estimated for: Malonyldialdehyde (MDA), Tumor necrosis factor alpha $(\mathrm{TNF} \alpha)$, glutathione $(\mathrm{GSH})$ and superoxide dismutase (SOD).At the end of experimental period, all samples was subjected to the following investigations: Measurement of SFBG ${ }^{\text {[19], }}$ urea and BUN ${ }^{[20]}$, creatinine ${ }^{[21]}, \mathrm{GSH}^{[22]}, \mathrm{SOD}^{[23]}$, $\mathrm{MDA}^{[24]}, \mathrm{TNF}^{[25]}$ and total protein in urine ${ }^{[26]}$.

Histopathological examination of the kidney: Kidneys were fixed in $10 \%$ formalin then dehydrated, embedded in paraffin, sectioned to 3-5 $\mu \mathrm{m}$ thickness, deparaffinized and rehydrated. Hematoxylin and Eosin (H\&E) dyes were used to stain the kidney tissues. The slides were then observed under light microscope ${ }^{[27] .}$

\section{Statistical Analysis}

Data were coded and entered using the statistical package for social science version16 (SPSS, 16) for windows. Quantitative data were expressed by using mean and standard error (S.E).Comparing between groups was done using one-way analysis of variance (one-way ANOVA) for comparison of quantitative data of more than 2 groups. The level of significance was taken at $p$ value of $\leq 0.05$.

\section{RESULTS}

Biochemical results: Table (1) \& figs. (1 and 2): Induction of DM caused significant increase in SFBG, urea, BUN, creatinine TNF $\alpha$, MDA and total protein with significant decrease in GSH and SOD versus control groups. Treatment with PGPE, sitagliptin or PGPE and sitagliptin simultaneously caused significant decrease in SFBG, urea, BUN, creatinine, $\mathrm{TNF} \alpha, \mathrm{MDA}$ and total protein with significant increase in GSH and SOD versus diabetic group. 
Table (1): Changes in different parameters among the studied animals groups: Serum fasting blood glucose, urea, blood urea nitrogen, creatinine, Tumor necrosis factor alpha level, Malonyldialdehyde, glutathione, Superoxide dismutase and 24 hours protein in urine

\begin{tabular}{|c|c|c|c|c|c|c|c|c|c|c|c|c|c|c|c|c|c|c|}
\hline \multirow{2}{*}{$\begin{array}{c}\text { Groups } \\
\text { Parameters }\end{array}$} & \multirow{2}{*}{$\begin{array}{c}\text { G I } \\
\text { Control } \\
\text { group } \\
\text { Mean } \\
\pm \text { SEM }\end{array}$} & \multicolumn{2}{|c|}{$\begin{array}{c}\text { G II } \\
\text { Control + } \\
\text { Buffer group }\end{array}$} & \multicolumn{3}{|c|}{$\begin{array}{c}\text { G III } \\
\text { Diabetic group }\end{array}$} & \multicolumn{4}{|c|}{$\begin{array}{c}\text { G IV } \\
\text { Diabetic +Punica group }\end{array}$} & \multicolumn{4}{|c|}{$\begin{array}{c}\text { G V } \\
\text { Diabetic +sitagliptin group }\end{array}$} & \multicolumn{4}{|c|}{$\begin{array}{c}\text { G VI } \\
\text { Diabetic +punica } \\
\text { \& sitagliptin group) }\end{array}$} \\
\hline & & $\begin{array}{l}\text { Mean } \\
\pm \text { SEM }\end{array}$ & $\begin{array}{l}\text { p vs. } \\
\text { G I }\end{array}$ & $\begin{array}{l}\text { Mean } \\
\pm \text { SEM }\end{array}$ & $\begin{array}{l}\text { P vs. } \\
\text { G I }\end{array}$ & $\begin{array}{l}\text { P. vs. } \\
\text { G II }\end{array}$ & $\begin{array}{l}\text { Mean } \\
\pm \text { SEM }\end{array}$ & $\begin{array}{c}\text { P vs. } \\
\text { G I }\end{array}$ & $\begin{array}{l}\text { P vs. } \\
\text { G II }\end{array}$ & $\begin{array}{l}\text { P vs. } \\
\text { G III }\end{array}$ & $\begin{array}{l}\text { Mean } \\
\pm \text { SEM }\end{array}$ & $\begin{array}{l}\text { P vs. } \\
\text { G I }\end{array}$ & $\begin{array}{l}\text { P vs. } \\
\text { G II }\end{array}$ & $\begin{array}{l}\text { P vs. } \\
\text { G III }\end{array}$ & $\begin{array}{l}\text { Mean } \\
\pm \text { SEM }\end{array}$ & $\begin{array}{l}\text { P vs. } \\
\text { G I }\end{array}$ & $\begin{array}{l}\text { P vs. } \\
\text { G II }\end{array}$ & $\begin{array}{l}\text { P vs. } \\
\text { G III }\end{array}$ \\
\hline SFBG (mg/dl) & $\begin{array}{l}102.50 \\
\pm 4.92\end{array}$ & $\begin{array}{l}101.00 \\
\pm 2.22\end{array}$ & 0.90 & $\begin{array}{c}507.43 \\
\pm 7.29\end{array}$ & $\begin{array}{c}0.001^{*} \\
\mathrm{~A}\end{array}$ & $\begin{array}{c}0.001^{*} \\
b\end{array}$ & $\begin{array}{r}156.57 \\
\pm 11.27\end{array}$ & $\begin{array}{c}0.001^{*} \\
\mathrm{~A}\end{array}$ & $\begin{array}{c}0.001^{*} \\
b\end{array}$ & $\begin{array}{c}0.001^{*} \\
\mathrm{C}\end{array}$ & $\begin{array}{l}158.86 \\
\pm 11.84\end{array}$ & $\begin{array}{c}0.001^{*} \\
\mathrm{a}\end{array}$ & $\begin{array}{c}0.001^{*} \\
b\end{array}$ & $\begin{array}{c}0.001^{*} \\
\mathrm{C}\end{array}$ & $\begin{array}{l}121.43 \\
\pm 7.46\end{array}$ & 0.13 & 0.10 & $\begin{array}{c}0.001^{*} \\
\mathrm{c}\end{array}$ \\
\hline Urea (mg/dl) & $\begin{array}{l}26.66 \\
\pm 4.96\end{array}$ & $\begin{array}{l}29.29 \\
\pm 0.59\end{array}$ & 0.54 & $\begin{array}{l}80.08 \\
\pm 3.68\end{array}$ & $\begin{array}{l}0.001^{*} \\
\text { a }\end{array}$ & $\begin{array}{c}0.001^{*} \\
\mathrm{~b}\end{array}$ & $\begin{array}{l}43.60 \\
\pm 1.59\end{array}$ & $\begin{array}{c}0.001^{*} \\
\mathrm{~A}\end{array}$ & $\begin{array}{c}0.001^{*} \\
\mathrm{~b}\end{array}$ & $\begin{array}{c}0.001^{*} \\
\mathrm{c}\end{array}$ & $\begin{array}{l}52.17 \\
\pm 2.68\end{array}$ & $\begin{array}{c}0.001^{*} \\
\mathrm{a}\end{array}$ & $\begin{array}{c}0.001^{*} \\
\mathrm{~b}\end{array}$ & $\begin{array}{l}0.001^{*} \\
\mathrm{C}\end{array}$ & $\begin{array}{l}39.43 \\
\pm 1.86\end{array}$ & $\begin{array}{c}0.001^{*} \\
\mathrm{~A}\end{array}$ & $\begin{array}{c}0.001^{*} \\
\mathrm{~b}\end{array}$ & $\begin{array}{l}0.02^{*} \\
\mathrm{c}\end{array}$ \\
\hline BUN (mg/dl) & $\begin{array}{l}14.77 \\
\pm 1.11\end{array}$ & $\begin{array}{l}15.28 \\
\pm 0.74\end{array}$ & 0.73 & $\begin{array}{l}37.71 \\
\pm 1.16\end{array}$ & $\begin{array}{c}0.001^{*} \\
\mathrm{a}\end{array}$ & $\begin{array}{c}0.001^{*} \\
\mathrm{~b}\end{array}$ & $\begin{array}{l}20.63 \\
\pm 0.62\end{array}$ & $\begin{array}{c}0.001^{*} \\
\mathrm{~A}\end{array}$ & $\begin{array}{c}0.001^{*} \\
\mathrm{~b}\end{array}$ & $\begin{array}{c}0.001^{*} \\
\mathrm{c}\end{array}$ & $\begin{array}{l}22.87 \\
\pm 0.70\end{array}$ & $\begin{array}{c}0.001^{*} \\
\mathrm{a}\end{array}$ & $\begin{array}{c}0.001^{*} \\
\mathrm{~b}\end{array}$ & $\begin{array}{l}0.001^{*} \\
\mathrm{C}\end{array}$ & $\begin{array}{l}17.11 \\
\pm 1.42\end{array}$ & 0.11 & 0.22 & $\begin{array}{c}0.001^{*} \\
\mathrm{c}\end{array}$ \\
\hline Creatinine (mg/dl) & $\begin{array}{c}0.70 \\
\pm 0.03\end{array}$ & $\begin{array}{c}0.70 \\
\pm 0.06\end{array}$ & 1.00 & $\begin{array}{c}1.83 \\
\pm 0.02\end{array}$ & $\begin{array}{l}0.001^{*} \\
\mathrm{a}\end{array}$ & $\begin{array}{c}0.00^{*} \\
\mathrm{~b}\end{array}$ & $\begin{array}{c}0.92 \\
\pm 0.09\end{array}$ & 0.07 & 0.07 & $\begin{array}{c}0.001^{*} \\
\mathrm{c}\end{array}$ & $\begin{array}{c}1.13 \\
\pm 0.14\end{array}$ & $\begin{array}{c}0.001^{*} \\
\mathrm{a}\end{array}$ & $\begin{array}{c}0.001^{*} \\
\mathrm{~b}\end{array}$ & $\begin{array}{l}0.001^{*} \\
\mathrm{C}\end{array}$ & $\begin{array}{c}0.91 \\
\pm 0.07\end{array}$ & 0.09 & 0.09 & $\begin{array}{c}0.001^{*} \\
\mathrm{c}\end{array}$ \\
\hline $\begin{array}{l}\text { TNFa }(p g / g . \\
\text { tissue) }\end{array}$ & $\begin{array}{l}23.42 \\
\pm 1.79\end{array}$ & $\begin{array}{l}19.77 \\
\pm 0.41\end{array}$ & 0.44 & $\begin{array}{l}95.26 \\
\pm 5.32\end{array}$ & $\begin{array}{c}0.001^{*} \\
\mathrm{a}\end{array}$ & $\begin{array}{c}0.001^{*} \\
b\end{array}$ & $\begin{array}{l}56.00 \\
\pm 3.94\end{array}$ & $\begin{array}{c}0.001^{*} \\
\text { A }\end{array}$ & $\begin{array}{c}0.001^{*} \\
b\end{array}$ & $\begin{array}{c}0.001^{*} \\
\mathrm{c}\end{array}$ & $\begin{array}{l}55.33 \\
\pm 1.88\end{array}$ & $0.001^{*}$ & $\begin{array}{c}0.001^{*} \\
b\end{array}$ & $\begin{array}{c}0.001^{*} \\
\mathrm{C}\end{array}$ & $\begin{array}{l}52.91 \\
\pm 2.28\end{array}$ & $\begin{array}{c}0.00^{*} \\
\mathrm{~A}\end{array}$ & $\begin{array}{c}0.001^{*} \\
b\end{array}$ & $\begin{array}{c}0.001^{*} \\
\mathrm{c}\end{array}$ \\
\hline $\begin{array}{l}\text { MDA (nmol / g. } \\
\text { tissue) }\end{array}$ & $\begin{array}{l}11.68 \\
\pm 0.69\end{array}$ & $\begin{array}{l}11.22 \\
\pm 0.25\end{array}$ & 0.85 & $\begin{array}{l}54.88 \\
\pm 3.24\end{array}$ & $\begin{array}{l}0.001^{*} \\
\text { a }\end{array}$ & $\begin{array}{c}0.001^{*} \\
\mathrm{~b}\end{array}$ & $\begin{array}{l}23.90 \\
\pm 1.52\end{array}$ & $\begin{array}{c}0.001^{*} \\
\text { A }\end{array}$ & $\begin{array}{c}0.001^{*} \\
\mathrm{~b}\end{array}$ & $\begin{array}{c}0.001^{*} \\
\mathrm{c}\end{array}$ & $\begin{array}{l}27.40 \\
\pm 1.06\end{array}$ & $\begin{array}{c}0.001^{*} \\
\mathrm{a}\end{array}$ & $\begin{array}{c}0.001^{*} \\
\mathrm{~b}\end{array}$ & $\begin{array}{l}0.001^{*} \\
\mathrm{C}\end{array}$ & $\begin{array}{l}21.33 \\
\pm 1.34\end{array}$ & $\begin{array}{c}0.001^{*} \\
\text { A }\end{array}$ & $\begin{array}{c}0.001^{*} \\
\text { B }\end{array}$ & $\begin{array}{c}0.001^{*} \\
\mathrm{c}\end{array}$ \\
\hline $\begin{array}{l}\text { GSH (mmol / g. } \\
\text { tissue) }\end{array}$ & $\begin{array}{l}66.45 \\
\pm 4.56\end{array}$ & $\begin{array}{l}59.65 \\
\pm 1.46\end{array}$ & 0.14 & $\begin{array}{r}23.53 \\
\pm 3.02\end{array}$ & $\begin{array}{c}0.001^{*} \\
\text { a }\end{array}$ & $\begin{array}{c}0.001^{*} \\
\mathrm{~b}\end{array}$ & $\begin{array}{l}45.56 \\
\pm 3.20\end{array}$ & $\begin{array}{c}0.001^{*} \\
\mathrm{~A}\end{array}$ & $\begin{array}{c}0.001^{*} \\
\mathrm{~b}\end{array}$ & $\begin{array}{c}0.001^{*} \\
\mathrm{c}\end{array}$ & $\begin{array}{l}47.87 \\
\pm 1.78\end{array}$ & $\begin{array}{c}0.001^{*} \\
\mathrm{a}\end{array}$ & $\begin{array}{c}0.01^{*} \\
\mathrm{~b}\end{array}$ & $\begin{array}{l}0.001^{*} \\
\mathrm{C}\end{array}$ & $\begin{array}{l}57.01 \\
\pm 3.28\end{array}$ & $\begin{array}{c}0.03^{*} \\
\mathrm{a}\end{array}$ & 0.54 & $\begin{array}{l}0.001^{*} \\
\mathrm{c}\end{array}$ \\
\hline $\begin{array}{l}\text { SOD } \\
\text { (U/g.tissue) }\end{array}$ & $\begin{array}{c}5.87 \\
\pm 0.17\end{array}$ & $\begin{array}{l}5.53 \\
\pm 0.21\end{array}$ & 0.30 & $\begin{array}{c}1.45 \\
\pm 0.19\end{array}$ & $\begin{array}{l}0.001^{*} \\
\mathrm{a}\end{array}$ & $\begin{array}{c}0.001^{*} \\
\mathrm{~b}\end{array}$ & $\begin{array}{l}4.05 \\
\pm 0.10\end{array}$ & $\begin{array}{c}0.001^{*} \\
\mathrm{~A}\end{array}$ & $\begin{array}{c}0.001^{*} \\
\mathrm{~b}\end{array}$ & $\begin{array}{l}0.001^{*} \\
\mathrm{c}\end{array}$ & $\begin{array}{c}4.09 \\
\pm 0.21\end{array}$ & $\begin{array}{l}0.001^{*} \\
\mathrm{a}\end{array}$ & $\begin{array}{c}0.001^{*} \\
\mathrm{~b}\end{array}$ & $\begin{array}{l}0.001^{*} \\
\mathrm{C}\end{array}$ & $\begin{array}{c}4.83 \\
\pm 0.31\end{array}$ & $\begin{array}{c}0.001^{*} \\
\mathrm{~A}\end{array}$ & $\begin{array}{c}0.02^{*} \\
\mathrm{~b}\end{array}$ & $\begin{array}{l}0.001^{*} \\
\mathrm{c}\end{array}$ \\
\hline $\begin{array}{l}\text { Total protein in } \\
\text { urine } \\
\text { (mg/day) }\end{array}$ & $\begin{array}{c}2.73 \\
\pm 0.32\end{array}$ & $\begin{array}{c}3.07 \\
\pm 0.22\end{array}$ & 0.65 & $\begin{array}{l}37.28 \\
\pm 0.39\end{array}$ & $\begin{array}{c}0.001^{*} \\
\mathrm{a}\end{array}$ & $\begin{array}{c}0.001^{*} \\
\mathrm{~b}\end{array}$ & $\begin{array}{l}27.68 \\
\pm 0.65\end{array}$ & $\begin{array}{c}0.001^{*} \\
\mathrm{~A}\end{array}$ & $\begin{array}{c}0.001^{*} \\
b\end{array}$ & $\begin{array}{c}0.001^{*} \\
\mathrm{c}\end{array}$ & $\begin{array}{l}25.58 \\
\pm 0.57\end{array}$ & $\begin{array}{c}0.001^{*} \\
\mathrm{a}\end{array}$ & $\begin{array}{c}0.001^{*} \\
\mathrm{~b}\end{array}$ & $\begin{array}{l}0.001^{*} \\
\mathrm{c}\end{array}$ & $\begin{array}{l}22.20 \\
\pm 0.55\end{array}$ & $\begin{array}{c}0.001^{*} \\
\mathrm{~A}\end{array}$ & $\begin{array}{c}0.001^{*} \\
b\end{array}$ & $\begin{array}{l}0.001^{*} \\
\mathrm{c}\end{array}$ \\
\hline
\end{tabular}



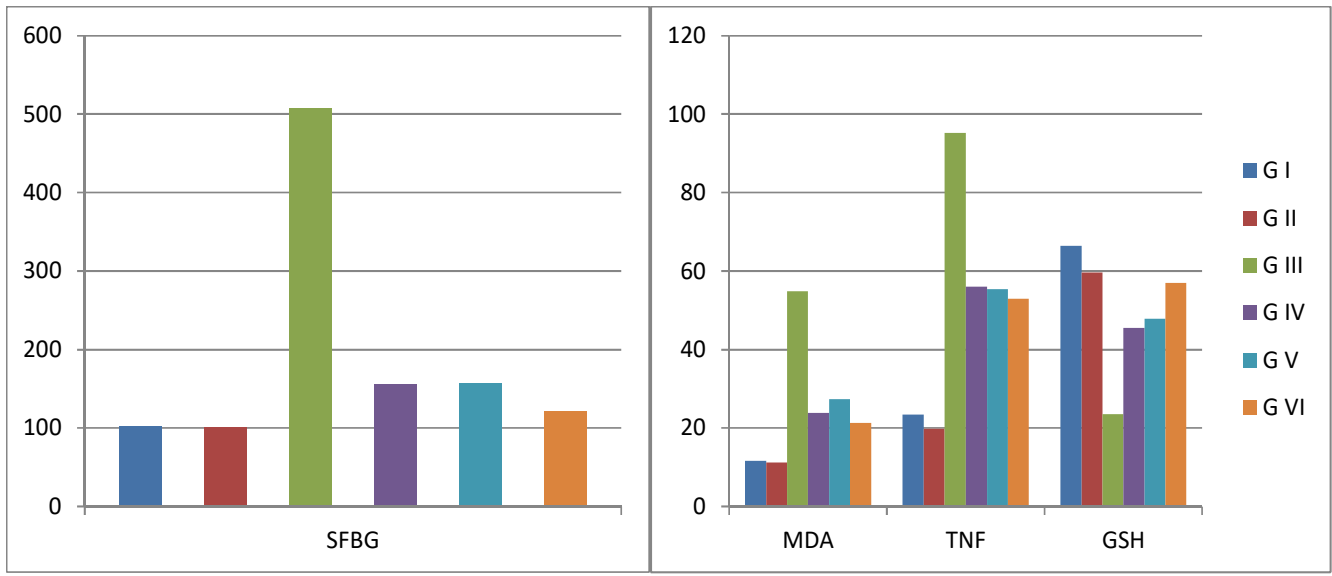

Figure (1): Changes in different parameters among studied animals groups: Serum fasting blood glucose (SFBG), Malonyldialdehyde (MDA), Tumor necrosis factor alpha level (TNFa) and glutathione (GSH).

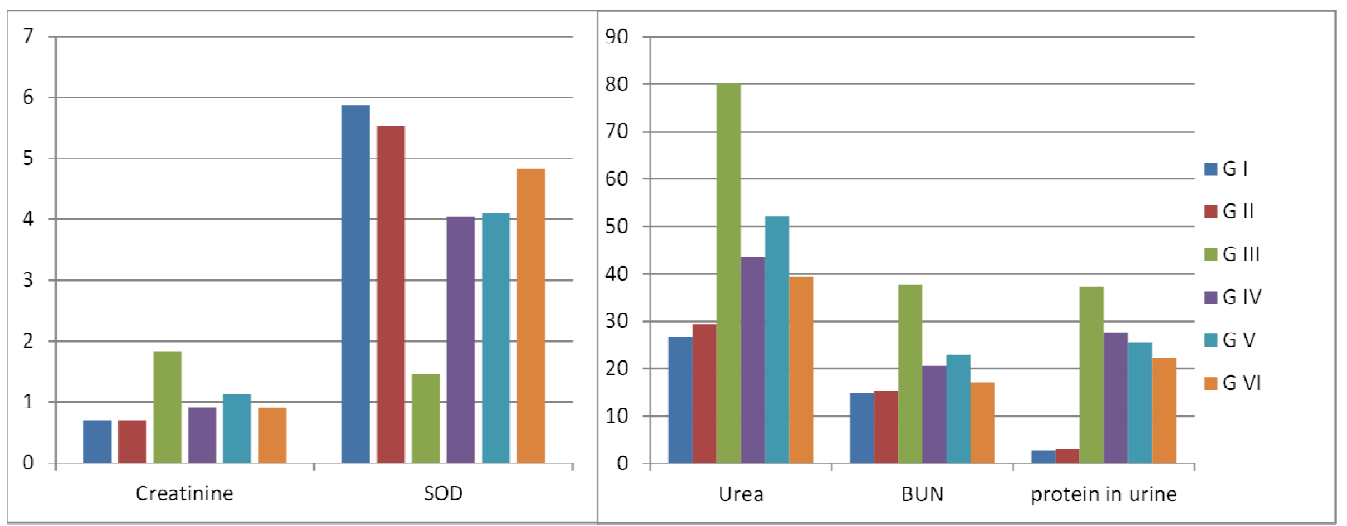

Figure (2): Changes in different parameters among studied animals groups: Superoxide dismutase (SOD), urea, blood urea nitrogen (BUN), creatinine and 24 hours protein in urine.

Histopathology : Control groups revealed normal tubular and glomerular structures(Fig.3).Diabetic rats revealed dilated glomerular space and dilated degenerated tubules (Fig.4).Diabetic rats treated by

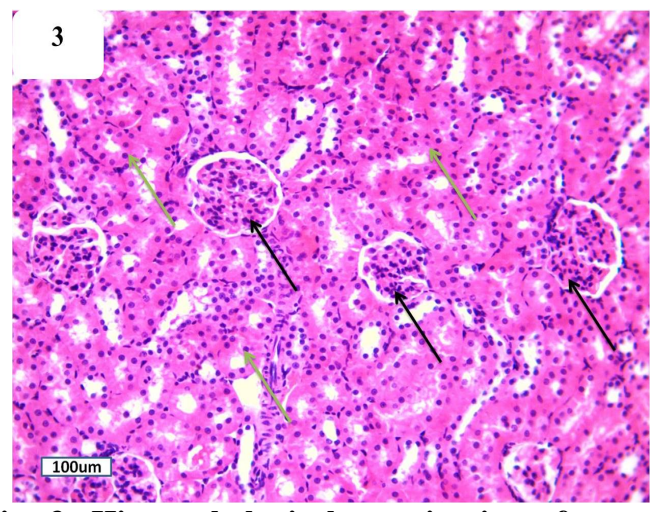

Fig. 3: Histopathological examination of control and control buffer group was similar: A photomicrograph of a section in a control rat kidney: showing the normal histological structure of the cortex, containing the glomeruli (black arrows) and renal tubules (green arrows) (H\&E X200). either PGPE or sitagliptin revealed some improvement in the glomerular space and most tubules (Figs. 5 and 6). Diabetic rats treated by both PGPE \&sitagliptin revealed the best results (Fig.7).

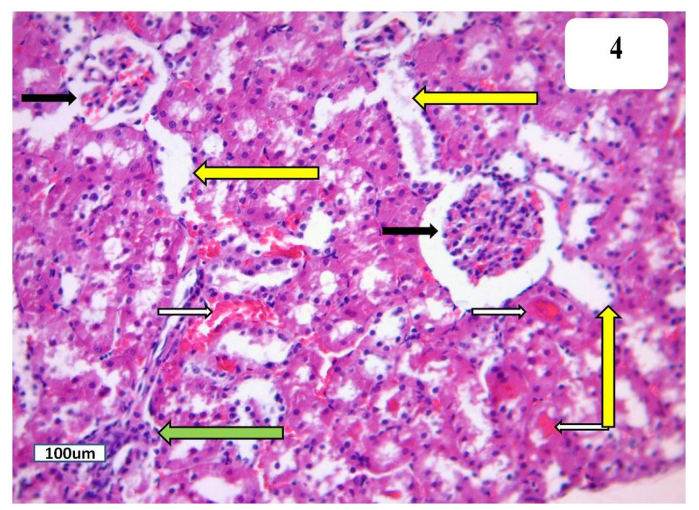

Fig. 4: A photomicrograph of a section in a diabetic rat kidney: showing mononuclear cell infiltration (green arrow), dilatation in the glomerular space (black arrow), vacuolated cytoplasm of the renal tubules (yellow arrows) and hemorrhage inside many tubules (white arrows) (H\&E X 200). 


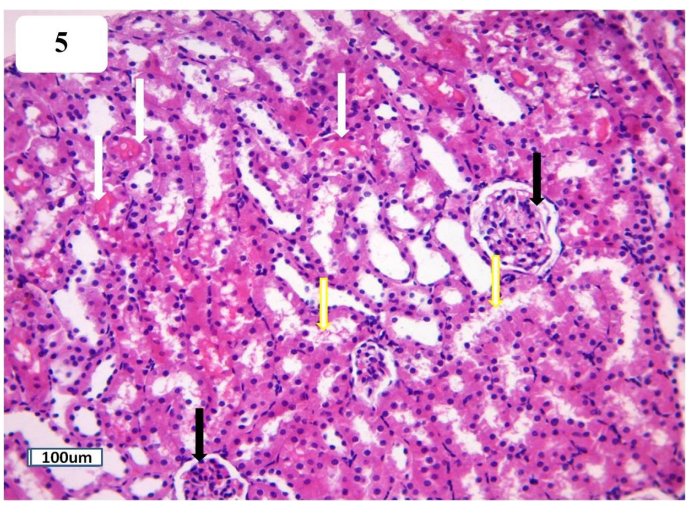

Fig. 5: A photomicrograph of a section of diabetic adult male rat kidney treated with Punica granatum peels extract (PGPE): showing decrease in the glomerular space (black arrows), but hemorrhage inside some tubules (white arrows) and vacuolated cytoplasm of some renal tubules (yellow arrows) are still present (H\&E X 200).

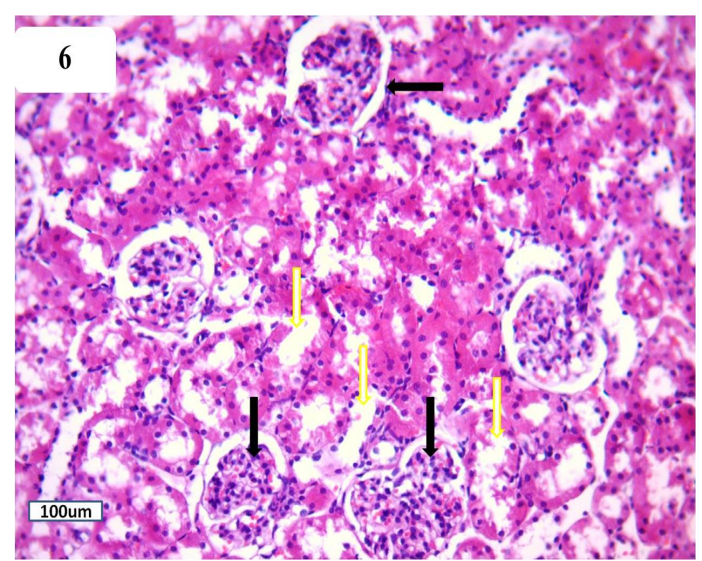

Fig. 6: A photomicrograph of a section of diabetic adult male rat kidney treated with sitagliptin: showing decrease in the glomerular space (black arrows) but some dilated renal tubules with vacuolated cytoplasm (yellow arrows) are still observed (H\&E X 200).

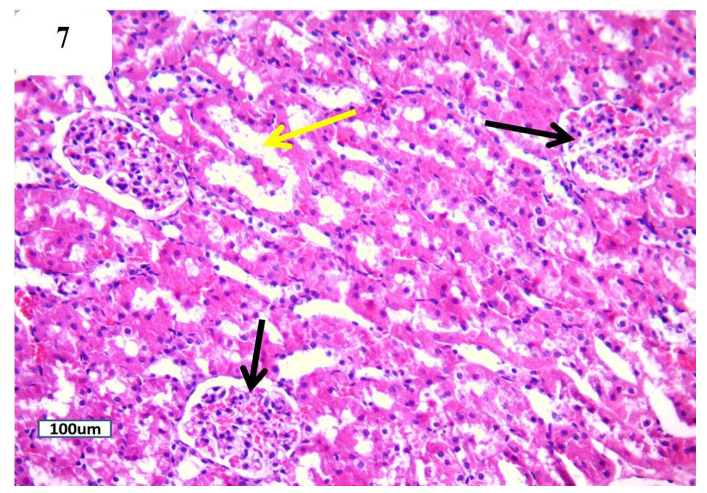

Fig.7: A photomicrograph of a section of a diabetic adult male rat kidney treated with Punica granatum peels extract (PGPE) and sitagliptin: showing decrease in the glomerular space (black arrows), but vacuolated cytoplasm of some renal tubules (yellow arrow) is still noted (H\&E X 200).

\section{DISCUSSION}

In the present study, there was a significant increase in SFBG in diabetic group versus control groups. In agreement with our results ${ }^{[28]}$ increased glucose level in diabetic rats.

Streptozotocin (STZ) after administration is rapidly enters into the pancreatic beta cells and leads to breakage of DNA strands ${ }^{[29-30]}$. STZ leads to generation of ROS which leads to DNA fragmentation in the pancreatic B-cell islets by increasing $\mathrm{H}_{2} \mathrm{O}_{2}$ production ${ }^{\text {[31] }}$. Alterations of the damaged pancreatic islets due to induction of diabetes, is accompanied by increased blood glucose [32- 33].

In the present study, there was a significant increase of urea, BUN, creatinine and total protein in diabetic group versus control groups. The effect of Streptozotocin-nicotinamide (STZ-NIC) could be proved by the present work histopathological finding. The kidney sections showed dilated glomerular space, dilated degenerated tubules and vacuolated cytoplasm of many renal tubules. In agreement with our results ${ }^{[34]}$ increased total protein, BUN, urea and creatinine levels in diabetic rats. The histopathological findings were in consistence with the study of ${ }^{[35-36]}$ who found dilated glomerular space, increased vacuolization of the cytoplasm and dilated degenerated tubules.

In $2016^{\text {[37] }}$ proved that diabetes can decrease the glomerular filtration rate by damaging the renal blood vessels. So, less BUN, creatinine and urea filtered out as they are excreted in the urine. Increased serum creatinine may be due to damaged muscles ${ }^{[38]}$. Recently ${ }^{[39]}$ suggested that diabetes weakens the glomerular filtration barrier, leads to glomerular damage and increased glomerular permeability to protein leading to albumin leakage. Also, ${ }^{[40]}$ found that T2DM causes a marked decrease in the tubular brush border thickness. The renal tubular structural abnormalities could disturb the normal fluid uptake leading to proteinuria.

In the present study, diabetic group showed significant increase of TNF- $\alpha$ and MDA. Significant decrease in SOD and GSH versus control groups. In agreement with this result ${ }^{[41-42]}$ increased TNF- $\alpha$ and MDA with decreased SOD and GSH levels in diabetic rats.

Oxidative stress is one of the most basic causes of chronic complications of T2DM.It leads to production of many oxidative intermediates, resulting in exacerbated oxidative damage ${ }^{[39]}$.

SOD is the first barrier to free radical and one of the most important antioxidant enzymes which convert superoxide radicals into the hydrogen peroxide. Also, GSH protects cells from oxidative damage; it helps 
glutathione peroxidase in scavenging free radicals. So, their levels decrease in oxidative stress ${ }^{[43-44]}$.

TNF- $\alpha$ is an inflammatory cytokine which is secreted from the macrophages. TNF- $\alpha$ suppresses insulin secretion in DM ${ }^{[45]}$. Free radicals over production cause DNA damage especially strand breakage and base alterations, which induce cell cycle arrest or apoptosis. Inflammation develops as a response to OS-induced damage involving activation of the nuclear factor kappa $\mathrm{B}(\mathrm{NF}-\mathrm{\kappa B})$ pathway in the renal cells. Chemokines, such as monocyte chemotactic protein-1 (MCP-1) and interleukins ${ }^{[46]}$ These proinflammatory adhesion molecules and chemokines attract monocytes, macrophages, and T lymphocytes, which infiltrate kidney tissue, resulting in activation of TNF- $\alpha$ signaling. Therefore, aggravation of kidney lesions ${ }^{[47] . ~ T N F-~} \alpha$ has a role in regulating apoptosis and inflammatory processes in diabetes [48]. In addition, increased level of TNF- $\alpha$ could be due to lipids dysfunction, especially increased triglyceride (TG) in adipose cells causing its secretion from macrophage cells ${ }^{[49] \text {. }}$

Lipid peroxidation is a marker of oxidative stress, in which polyunsaturated fatty acids (PUFAs) interact with free radicals, leading to formation of MDA, which causes negative effects as cell necrosis and inflammation. Administration of PGPE caused significant decrease in SFBG versus diabetic group while SFBG remained significant higher than control groups.

Similar changes were recorded by ${ }^{[50]}$ who found that PGPE caused a significant decrease in SFBG versus diabetic group.

The hypoglycemic effect of PGPE related to its active substances (polyphenols and flavonoids) which have the properties of increasing insulin secretion, promoting glucose uptake by muscle or adipose tissues, regenerating pancreatic beta cell, decreasing glucose absorption from the intestine and glucose production from the liver ${ }^{\text {[51]. }}$ PGPE leads to increase insulin levels by increasing either pancreatic secretion of insulin or its release from the bound form ${ }^{[52]}$.

Administration of PGPE extract showed significant decrease in urea, BUN, creatinine and total protein levels versus diabetic group. However, levels of urea, BUN and total protein remained significant higher than control groups, while the creatinine returned almost back to control groups.

These results were in agreement with the finding of ${ }^{[53-54]}$ who found that PGPE cause decrease on serum creatinine, BUN, and urea. Administration of PGPE causes a significant decrease in total protein ${ }^{[17]}$.

In kidney sections, PGPE treated animals showed moderate renal improvement, in glomerular space and most tubules. Some tubules dilated, others still vacuolated and hemorrhage was noted inside them.
The histopathological findings were in consistence with the study of ${ }^{[55-56]}$ who found significantly reduced vacuolar degeneration of tubules of the kidney and reduction of the thickened basement membrane in diabetic rats treated with PGPE.

The protective effect of PGPE on the creatinine and urea could be attributed to its antioxidant effect as ROS has been found to be involved in the impairment of glomerular filtration rate ${ }^{[57] \text {. }}$

The present study demonstrated that administration of PGPE induced a significant decrease in TNF- $\alpha$ and MDA. Significant increase in GSH and SOD levels versus diabetic group, while TNF- $\alpha$ and MDA levels remained significantly higher than the control groups. However, GSH and SOD levels remained significantly lower than the control groups. These results were in agreement with the finding of ${ }^{[53-55]}$ who recorded that administration of PGPE leading to reduction of TNF- $\alpha$ and MDA levels with significant increase in GSH and SOD levels.

The anti-inflammatory effects of PGPE happen via inhibition of cell signaling pathways including suppression of cyclo-oxygenase-2 and inducible nitric oxide expression, inhibition of activation of $\mathrm{NF}_{\mathrm{K}} \mathrm{B}$ and inhibition of phosphorylation of mitogenactivated protein kinase (MAPKs) proteins ${ }^{[58]}$. Phenolic compounds due to their redox properties contribute to the antioxidant activities of PGPE. They prevent decomposition of hydroperoxides into free radicals and neutralize lipid free radicals ${ }^{[59] . ~}$ On contrary to our results ${ }^{[60]}$ found that PGPE supplementation showed insignificant improvement in the activity of SOD and MDA, this may be due to different method in preparing the extract.

Administration of sitagliptin showed significant decrease in SFBG versus diabetic group, however level of SFBG remained significant higher than control groups. In agreement with our results [61] reported that sitagliptin caused decreased glucose level.

Sitagliptin is a DPP-IV inhibitor which improves glucose level by stimulating insulin secretion results from GLP-1R activation in the pancreas. GLP-1 can inhibit glucagon secretion in a glucose-dependent manner by its effect on pancreatic alpha cells and, thereby improving glycemic control with decrease the risk of hypoglycemia ${ }^{[62-63]}$.

Administration of sitagliptin showed a significant decrease in urea, BUN, creatinine and total protein versus diabetic group. However, levels of urea, BUN, creatinine and total protein remained significant higher than control groups. Similar changes were recorded by ${ }^{[64-65]}$ who reported that sitagliptin caused a significant decrease in urea, BUN, creatinine and total protein levels versus diabetic group. 
In kidney sections of sitagliptin treated rats showed improvement of the glomerular spaces and most tubules versus diabetic group, but some tubules still dilated and others degenerated. The histopathological findings were in consistence with the study of ${ }^{[47]}$ who found that diabetic rats treated with sitagliptin showed improvement in the morphological changes and the infiltration of inflammatory cells.

Sitagliptin has renoprotective effects via the antiinflammatory and anti-oxidant actions [66]. It also might be associated with the attenuation of podocyte injury [67]. Sitagliptin reduces albuminuria by controlling of blood sugar ${ }^{[68-69]}$. Also, it has been shown to inhibit renal tubular sodium reabsorption so increase the glomerular pressure and reduce the albuminuria [70]. On contrast to our results [71, 72,73] reported that sitagliptin has no effect on the creatinine, urea and BUN levels. This might be related to the extremely high urinary concentrations that result from rapid renal elimination of the drug as seen in rodents.

Administration of sitagliptin showed a significant decrease in TNF- $\alpha$ and MDA, significant increase in GSH and SOD versus diabetic group, while TNF- $\alpha$ and MDA remained significant higher than control groups, however GSH and SOD remained significant lower than control groups. In agreement with these results ${ }^{[73-73]}$ found that administration of sitagliptin caused a significant decrease in TNF- $\alpha$ and MDA, significant increase in GSH and SOD versus diabetic group.

Sitagliptin treatment decreased the proinflammatory cytokine genes expression such as TNF- $\alpha$ in the kidney of diabetic rat ${ }^{[75] . ~ R e n a l ~ c y c l i c ~ a d e n o s i n e ~}$ monophosphate (cAMP) production is up regulated by sitagliptin through elevating circulatory stromal cell-derived factor-1a. Another mechanism is that sitagliptin elevates active GLP_1, which is known to up regulate cAMP. Increased cAMP has antioxidative effects and reduces reactive oxygen species, which are a major cause of $\mathrm{DN}^{\text {[Error! Reference }}$ source not found.].

There was no previous studies discussed the effect of combined PGPE and sitagliptin. Therefore, the obtained results reflect the cumulative effects of both PGPE and sitagliptin with their underlying mechanism of action. Concomitant administration of PGPE and sitagliptin showed significant decrease in SFBG, urea, BUN, creatinine, total protein, MDA and TNFa. Significant increase in GSH and SOD versus diabetic group. SFBG, BUN and creatinine returned almost back to control groups, while urea, total protein, MDA and TNF $\alpha$ remained significantly higher than that of control groups. SOD remained significantly lower than that of control groups. GSH returned back to control buffer group but remained significantly lower than control group. Co- administration of PEPE and sitagliptin induced the best improvement of the histopathological results of renal tissues where the histopathological picture of the kidney tends to be normal. However, some renal tubules still having vacuolated cytoplasm.

\section{CONCLUSIONS}

The result of the present study showed that combination of PGPE and sitagliptin have synergistic effects for each other compared to monotherapy and have a better renoprotective effects in diabetic rats. The concomitant administration of PGPE along with sitagliptin not only attenuated the glucose homeostasis but also showed significant improvement in renal functions, inflammatory and antioxidant markers. So, it is recommended that: PGPE is worthy of further investigations as they are safe and effective for modulating DM and its complications (DN). Additional clinical trials are needed to support the use of sitagliptin and PGPE as preventive or therapeutic agents in patients with DN.

\section{Conflicts of interest}

There are no conflicts of interest.

\section{Acknowledgment}

I would like to express deep thanks to professor Dr. Salwa Abdel Raouf Ibrahim, professor of histology, faculty of medicine for girls, Al-Azhar University, for her effort and cooperation in the present work.

\section{REFERENCES}

1. Lorber D. Importance of cardiovascular disease risk management in patients with type 2 diabetes mellitus. Diabetes Metab Syndr Obes., 2014 7:169-83.

2. Livingstone R, Boyle JG, Petrie JR and on behalf of the REMOVAL Study Team. A new perspective on metformin therapy in type 1 diabetes. Diabetologia. 2017, 60(9): pp.15941600.

3. Yang S, Zhang J, Feng C, Huang G. MTHFR $677 \mathrm{~T}$ variant contributes to diabetic nephropathy risk in Caucasian individuals with type 2 diabetes: a meta-analysis. Metabolism. 2013; 62(4): pp.586-594.

4. Kuhad A, Chopra K. Attenuation of diabetic nephropathy by tocotrienol: Involvement of NFkappaB signalling pathway. Life Sci., 2009; 84:296-301.

5. Vinod PB. Pathophysiology of diabetic nephropathy. Clin Queries Nephrol. 2012; 1:121-6.

6. Luo ZF, Feng B, Mu J, Qi W, Zeng W, Guo YH, et al. Effects of 4-phenylbutyric acid on the process and development of diabetic nephropathy induced in rats by streptozotocin: regulation of endoplasmic reticulum stressoxidative activation. Toxicology and applied pharmacology. 2010; 246(1-2): pp.49-57.

7. Jensen EP, Poulsen SS, Kissow H, HolsteinRathlou NH, Deacon CF, Jensen BL, et al. 
Activation of GLP-1 receptors on vascular smooth muscle cells reduces the autoregulatory response in afferent arterioles and increases renal blood flow. American Journal of Physiology-Renal Physiology. 2015; 308(8): pp.F867-F877.

8. Matsui T, Nakashima S, Nishino Y, Ojima A, Nakamura N, Arima K, et al. Dipeptidyl peptidase-4 deficiency protects against experimental diabetic nephropathy partly by blocking the advanced glycation end productsreceptor axis. Laboratory Investigation. 2015; 95(5): p.525.

9. Herman GA, Bergman A, Liu F, Stevens C, Wang AQ, Zeng W, et al. Pharmacokinetics and pharmacodynamic effects of the oral DPP-4 inhibitor sitagliptin in middle-aged obese subjects. The Journal of Clinical Pharmacology. 2006; 46(8): pp.876-886.

10. Rathod NR, Biswas D, Chitme HR, Ratna S, Muchandi IS, Chandra R. Anti-urolithiatic effects of Punica granatum in male rats. Journal of ethnopharmacology. 2012; 140(2): pp.234238 .

\section{Patil US, Bandawane DD, Bibave KH,} Chaudhari PD. Antihyperglycemic and in vitro antioxidant activities of Punica granatum Linn. In alloxan induced diabetic rats. Ind Drugs. 2013; 50:39-46.

12. Garach D, Pake A, Chakraborty $M$ and Kamath JV. Phytochemical and pharmacological profile of Punica granatum: an overview. Intr Res J Pharm. 2013; 3 (2): 65, 68.

13. Mega $C$, Teixeira de Lemos E, Vala $H$, Fernandes R, Oliveira J, Mascarenhas-Melo F, et al. Diabetic nephropathy amelioration by a low-dose sitagliptin in an animal model of type 2 diabetes (Zucker diabetic fatty rat). Exp Diabetes Res. 2011; (1): 162092.

14. Naidu PB, Uddandrao VS, Naik RR, Pothani S, Munipally PK, Meriga B, et al. Effects of Sallylcysteine on biomarkers of the polyol pathway in rats with type 2 diabetes. Canadian journal of diabetes. 2016; 40(5): pp.442-448.

15. Uddandrao VS, Brahmanaidu P, Ravindarnaik R, Suresh P, Vadivukkarasi S, Saravanan G. Restorative potentiality of Sallylcysteine against diabetic nephropathy through attenuation of oxidative stress and inflammation in streptozotocin-nicotinamideinduced diabetic rats. European journal of nutrition. 2018; pp.1-13.

16. Saad EA, Hassanien MM, El-Hagrasy MA, Radwan KH. Antidiabetic, hypolipidemic and antioxidant activities and protective effects of Punica granatum peels powder against pancreatic and hepatic tissues injuries in streptozotocin induced IDDM in rats. Int $\mathbf{J}$ Pharm Pharm Sci. 2015; 7(7): pp.397-402.
17. Ankita P, Deepti B, Nilam M. Flavonoid rich fraction of Punica granatum improves early diabetic nephropathy by ameliorating proteinuria and disturbed glucose homeostasis in experimental animals. Pharmaceutical biology. 2015; 53(1): 61-71.

18. Tuck MK, Chan DW, Chia D, Godwin AK, Grizzle WE, Krueger KE, et al. Standard operating procedures for serum and plasma collection: early detection research network consensus statement standard operating procedure integration working group. Journal of proteome research. 2008; 8(1): 113-117.

19. Trinder P. Determination of glucose in blood using glucose oxidase with an alternative oxygen acceptor. Annals of clinical Biochemistry. 1969; 6(1): 24-27.

20. Batton CJ, Crouch SR. Spectrophotometer investigation of urea. Analytical chemistry. 1977; 49: 464-469.

21. Young DS. Effects of disease on Clinical Lab. Tests, 4th ed. 2001; AACC. pp.1-1850.

22. Beutler E. Improved method for the determination of blood glutathione. Journal of laboratory and clinical medicine. 1963; 61: 882888 .

23. Nishikimi M, Rao NA, Yagi K. The occurrence of superoxide anion in the reaction of reduced phenazine methosulfate and molecular oxygen. Biochemical and biophysical research communications. 1972; 46(2): 849-854.

24. Ohkawa H, Ohishi N, Yagi K. Assay for lipid peroxides in animal tissues by thiobarbituric acid reaction. Analytical biochemistry. 1979; 95(2): 351-358.

25. Dowlati Y, Herrmann N, Swardfager W, Liu H, Sham L, Reim EK, et al. A meta-analysis of cytokines in major depression. Biological psychiatry. 2010; 67(5): 446-457.

26. Bakker AJ, Mücke M. Gammopathy interference in clinical chemistry assays: mechanisms, detection and prevention. Clinical Chemical Laboratory Medicine. 2007; 45(9):1240-1243.

27. Palipoch S, Punsawad C. Biochemical and histological study of rat liver and kidney injury induced by Cisplatin. Journal of Toxicologic Pathology. 2013; 26(3):293-299.

28. Asokan SM, Wang RY, Hung TH, Lin WT. Hepato-protective effects of Glossogyne tenuifolia in Streptozotocin-nicotinamideinduced diabetic rats on high fat diet. BMC complementary and alternative medicine. 2019; 19(1): 117.

29. Mali KK, Ligade SS, Dias RJ. Delaying effect of polyherbal formulation on cataract in STZNIC-induced diabetic wistar rats. Indian Journal of pharmaceutical sciences. 2019; 81(3): 415423.

30. Shivavedi N, Tej GNVC, Neogi K, Nayak PK. Ascorbic acid therapy: A potential strategy 
against comorbid depression-like behavior in streptozotocin-nicotinamide-induced diabetic rats. Biomedicine \& Pharmacotherapy. 2019; 109: 351-359

31. Ullah R, Tariq SA, Khan N, Sharif N. Lipid Lowering Effect of Methanol Extract of Tamarix-aphylla L. Karst (Saltcedar) in Streptozocin-Nicotinamide Induced Diabetic Rats. J Diabetes Treat. 2017; pp.1-6.

32. Elkotby D, Hassan AK, Emad R, Bahgat I. Histological changes in islets of Langerhans of pancreas in alloxan-induced diabetic rats following Egyptian honey bee venom treatments. International Journal of Pure and Applied Zoology. 2018; 6: 1-6.

33. Al-Attar AM, Alsalmi FA. Effect of Olea europaea leaves extract on streptozotocin induced diabetes in male albino rats. Saudi journal of biological sciences. 2019; 26(1): 118128.

34. Goli F, Karimi J, Khodadadi I, Tayebinia H, Kheiripour N, Hashemnia M, et al. Silymarin attenuates ELMO-1 and KIM-1 expression and oxidative stress in the kidney of rats with type 2 diabetes. Indian Journal of Clinical Biochemistry. 2019; 34(2): 172-179.

35. Kaushik P, Lal S, Kaushik D. Evaluation of Pinus roxburghii Sarg. In STZ induced Diabetic Nephropathy. Global Journal of Pharmaceutical Education and Research. 2018; 6(1-2).

36. Indu R, Adhikari A, Basak P, Sur TK. Effect of concomitant therapy of anti-diabetics and hypolipidemics on biochemical and histological parameters in animal models. Asian Journal of Pharmacy and Pharmacology. 2019; 5(4): 771778.

37. Bamanikar SA, Bamanikar AA, Arora A. Study of Serum urea and Creatinine in Diabetic and nondiabetic patients in a tertiary teaching hospital. The Journal of Medical Research. 2016; 2(1):12-15.

38. Afzal M, Saleem S, Singh N, Kazmi I, Khan R, Nadeem MS, et al. Evaluation of diphenhydramine in talc induced type 2 diabetes mellitus in Wistar rats. Biomedicine \& Pharmacotherapy. 2018; 97: 652-655.

39. Cheng D, Gao L, Su S, Sargsyan D, Wu R, Raskin I, et al. Moringa Isothiocyanate activates Nrf2: Potential Role in Diabetic Nephropathy. The American Association of Pharmaceutical Scientists journal. 2019; 21(2):31.

40. Zayed AE, Saleh A, Gomaa A, AbdElkareem M, Anwar MM, Hassanein K, et al. Protective effect of Ginkgo biloba and magnetized water on nephropathy in induced type 2 diabetes in rat. Oxidative medicine and cellular longevity. 2018; p.7.

41. Zhao LL, Makinde EA, Shah MA, Olatunji OJ, Panichayupakaranant P.
Rhinacanthins-rich extract and rhinacanthin C ameliorate oxidative stress and inflammation in streptozotocin-nicotinamide-induced diabetic nephropathy. Journal of Food Biochemistry, 2019; 43(4): e12812.

42. Balakrishnan BB, Krishnasamy K, Mayakrishnan V. Selvaraj A. Moringa concanensis Nimmo extracts ameliorates hyperglycemia-mediated oxidative stress and upregulates PPAR $\gamma$ and GLUT4 gene expression in liver and pancreas of streptozotocinnicotinamide induced diabetic rats. Biomedicine \& Pharmacotherapy. 2019: 112: p.108688.

43. Sadi G, Şahin G, Bostanci A. Modulation of renal insulin signaling pathway and antioxidant enzymes with streptozotocin-induced diabetes: effects of resveratrol. Medicina. 2019; 55(1): p.3.

44. Zhao X, Yang D, Xu W, Xu W, Guo Z. Effect of Irbesartan on Oxidative Stress and Serum Inflammatory Factors in Renal Tissues of Type 2 Diabetic Rats. Journal of the College of Physicians and Surgeons-Pakistan. 2019; 29(5): 422-425.

45. Mahmoodi M, Koohpeyma F, Saki F, Maleksabet A. The protective effect of Zataria multiflora Boiss. hydroalcoholic extract on TNF$\alpha$ production, oxidative stress, and insulin level in streptozotocin-induced diabetic rats. Avicenna journal of phytomedicine. 2019; 9(1): p.72.

46. Sifuentes-Franco S, Padilla-Tejeda DE, Carrillo-Ibarra S, Miranda-Díaz AG. Oxidative stress, apoptosis, and mitochondrial function in diabetic nephropathy. International journal of endocrinology. 2018; pp.1-9.

47. Wang J, Hu L, Chen Y, Fu T, Jiang T, Jiang A, et al. Sitagliptin improves renal function in diabetic nephropathy in male Sprague Dawley rats through upregulating heme oxygenase-1 expression. Endocrine. 2019; 63(1): 70-78.

48. Safhi MM, Alam MF, Sivakumar SM, Anwer T. Hepatoprotective Potential of Sargassum muticum against STZ-Induced Diabetic Liver Damage in Wistar Rats by Inhibiting Cytokines and the Apoptosis Pathway. Analytical Cellular Pathology. 2019; pp.1-9.

49. Szpigel A, Hainault I, Carlier A, Venteclef N, Batto AF, Hajduch E, et al. Lipid environment induces ER stress, TXNIP expression and inflammation in immune cells of individuals with type 2 diabetes. Diabetologia. 2018; 61(2): 399-412.

50. El-Hadary AE, Ramadan MF. Phenolic profiles, antihyperglycemic, antihyperlipidemic, and antioxidant properties of pomegranate (Punica granatum) peel extract. Journal of Food Biochemistry. 2019; 43(4): e12803.

51. Hasona NASA, Qumani MA, Alghassab TA, Alghassab MA, Alghabban AA. Ameliorative properties of Iranian Trigonella foenum-graecum L. seeds and Punica granatum L. peel extracts in 
streptozotocin-induced experimental diabetic guinea pigs. Asian Pacific Journal of Tropical Biomedicine. 2017; 7(3): 234-239.

52. Middha SK, Usha T, Pande V. Insights into the causes and anti-hyperglycemic effects of Punica granatum rind in alloxan-induced diabetic rats. Chiang Mai J Sci. 2016; 43: 112-122.

53. Karwasra R, Kalra P, Gupta YK, Saini D, Kumar A, Singh S. Antioxidant and antiinflammatory potential of pomegranate rind extract to ameliorate cisplatin-induced acute kidney injury. Food \& function. 2016; 7(7): 3091-3101.

54. Mobasher Ahmad RW, Anwar R, Kamran SH, Mobasher A, Akhtar U. Prophylactic and protective activity of crude and methanolic extract of punica granatum peel against gentamicin induced nephrotoxicity. 2017; pp.17.

55. Mestry SN, Dhodi JB, Kumbhar SB, Juvekar AR. Attenuation of diabetic nephropathy in streptozotocin-induced diabetic rats by Punica granatum Linn. Leaves extract. Journal of traditional and complementary medicine. 2017; 7(3): 273-280.

56. Manna K, Mishra S, Saha M, Mahapatra S, Saha C, Yenge G, et al. amelioration of diabetic nephropathy using pomegranate peel extractstabilized gold nanoparticles: assessment of NF$\kappa \mathrm{B}$ and Nrf2 signaling system. International journal of nanomedicine. 2019; 14: 1753.

57. Mestry SN, Gawali NB, Pai SA, Gursahani MS, Dhodi JB, Munshi R, et al. Punica granatum improves renal function in gentamicininduced nephropathy in rats via attenuation of oxidative stress. Journal of Ayurveda and integrative medicine. 2017; pp.1-9.

58. Ghavipour M, Sotoudeh G, Tavakoli E, Mowla K, Hasanzadeh J, Mazloom Z. Pomegranate extract alleviates disease activity and some blood biomarkers of inflammation and oxidative stress in Rheumatoid Arthritis patients. European journal of clinical nutrition. 2017; 71(1): p.92.

59. El Sayed AS, Badawi AM, Asmaa MT. The protective effect of olive leaf and pomegranate peel extracts on oxidative stress and liver injury induced by oxytetracycline in albino rats. Egypt. J. Drug Res. Egypt, 2014 35, pp.33-41.

60. Afreen SA, Khan MM, Ali SA. Antidiabetic effect of Punica Granatum Peel Extract, Spilanthes Paniculata Flower Extract and Selenium in Streptozotocin Induced Diabetes. International Journal of Pharmaceutical Research \& Allied Sciences. 2015; 4(2): 112-118.

61. Samaha MM, Said E, Salem HA. A comparative study of the role of crocin and sitagliptin in attenuation of STZ-induced diabetes mellitus and the associated inflammatory and apoptotic changes in pancreatic $\beta$-islets. Environmental Toxicology and Pharmacology. 2019; p.103238: 1-11.

62. Tsurutani Y, Omura M, Matsuzawa Y, Saito J, Higa M, Taniyama M, et al. Efficacy and safety of the dipeptidyl Peptidase-4 inhibitor Sitagliptin on atherosclerosis, $\beta$-cell function, and glycemic control in Japanese patients with type 2 diabetes mellitus who are treatment Naïve or poorly responsive to Antidiabetes agents: a multicenter, prospective observational, uncontrolled study. Current Therapeutic Research. 2017; 84: 26-31.

63. Jameshorani M, Sayari S, Kiahashemi N, Motamed N. Comparative study on adding pioglitazone or sitagliptin to patients with type 2 diabetes mellitus insufficiently controlled with metformin. Open access Macedonian journal of medical sciences. 2017; 5(7): p.955.

64. Wang Q, Long M, Qu H, Shen R, Zhang R, $\mathbf{X u}$ J, et al. DPP-4 inhibitors as treatments for type 1 diabetes mellitus: a systematic review and meta-analysis. Journal of diabetes research, 2018, pp.1-10.

65. Xu L, Ren Y. Sitagliptin inhibits cell apoptosis and inflammation of renal tissues in diabetic nephropathy model rats. Chinese journal of cellular and molecular immunology. 2019; 35(3): 217-222.

66. Kim MK. Treatment of diabetic kidney disease: current and future targets. The Korean journal of internal medicine. 2017; 32(4): p.622.

67. Qiu DD, Liu J, Shi JS, An Y, Ge YC, Zhou ML, et al. Renoprotection provided by dipeptidyl peptidase- 4 inhibitors in combination with angiotensin receptor blockers in patients with type 2 diabetic nephropathy. Chinese medical journal. 2018; 131(22): p.2658.

68. Hattori S. Sitagliptin reduces albuminuria in patients with type 2 diabetes [Rapid Communication]. Endocrine journal. 2011; 58(1): pp.69-73.

69. Liu W, Yu J, Yan Q, Wang L, Li N, Xiong W. Meta-analysis of the benefit of sitagliptin treatment in patients with type 2 diabetes complicated with incipient nephropathy. Experimental and therapeutic medicine. 2018; 16(3): 2545-2553.

70. Kim Y, Park CW. New therapeutic agents in diabetic nephropathy. The Korean journal of internal medicine. 2017; 32(1): p.11.

71. Kröller-Schön S, Knorr M, Hausding M, Oelze M, Schuff A, Schell R, et al. Glucoseindependent improvement of vascular dysfunction in experimental sepsis by dipeptidyl-peptidase 4 inhibition. Cardiovascular research. 2012; 96(1): 140-149.

72. Olurishe CO, Kwanashie HO, Zezi AU, Danjuma NM, Mohammed B. SitagliptinMoringa oleifera coadministration did not delay the progression nor ameliorated functional and morphological anomalies in alloxan-induced 
diabetic nephropathy. Indian journal of pharmacology. 2017; 49(5): p.366.

73. Marques C, Gonçalves A, Pereira PMR, Almeida D, Martins B, Fontes-Ribeiro C, et al. The dipeptidyl peptidase 4 inhibitor sitagliptin improves oxidative stress and ameliorates glomerular lesions in a rat model of type 1 diabetes. Life sciences. 2019; 234, p.116738: 1-9.

74. Maheshwari R, Balaraman $R$, Sen AK, Shukla D, Seth A. Effect of concomitant administration of coenzyme Q10 with sitagliptin on experimentally induced diabetic nephropathy in rats. Renal failure. 2017; 39(1): 130-139.

75. Lee YS, Jun HS. Anti-inflammatory effects of GLP-1-based therapies beyond glucose control. Mediators of inflammation. 2016; pp.111.

76. Kim YG, Byun J, Yoon D, Jeon JY, Han SJ, Kim DJ, et al. Renal protective effect of DPP-4 inhibitors in type 2 diabetes mellitus patients: a cohort study. Journal of diabetes research. 2016; pp.1-9. 


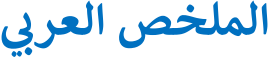 \\ آثار مستخلص قثرالرومان و / أو السيتاجلبتين على اعتلالّ" الكلية السكري المستحدث فى ذكور الفئران البيضاء البالغة أبنات

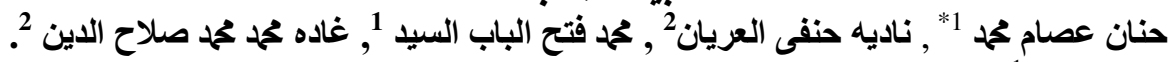

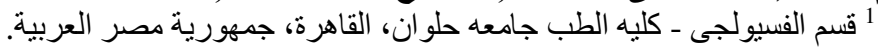

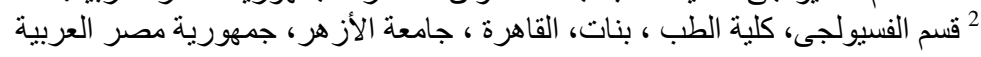 \\ ملخص البحث:}

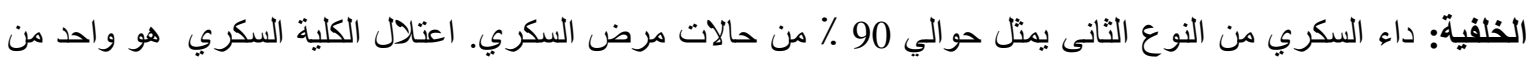

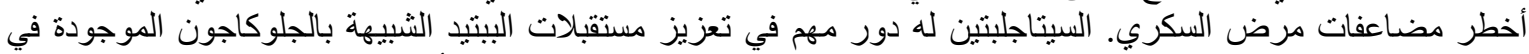

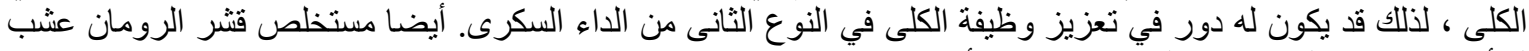
له أنشطة مضادة لفرط سكر الام ومضادات لأل الأكسدة.

الهرف: تم تصميم هذه الدراسة للتحقيق في دورمستخلص قنشر الرومان و / أو السيتاجلبتين على وظائف الكلى في مرض

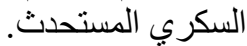

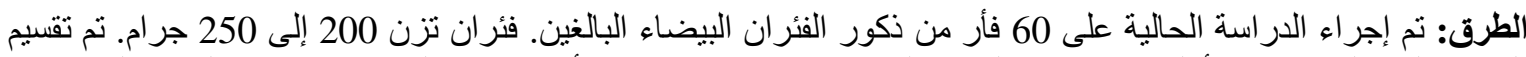

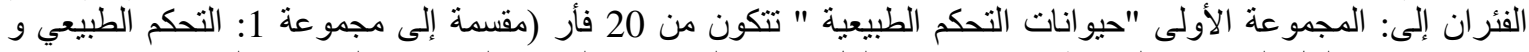

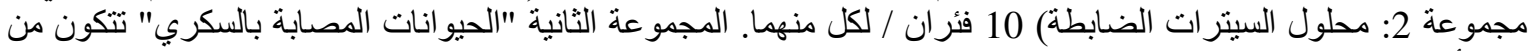

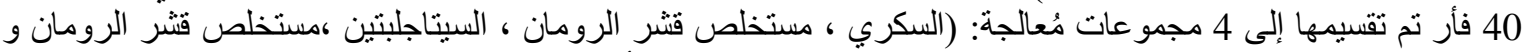

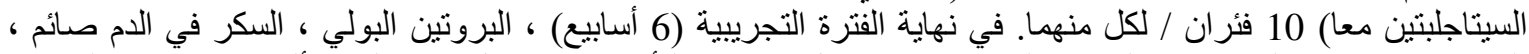

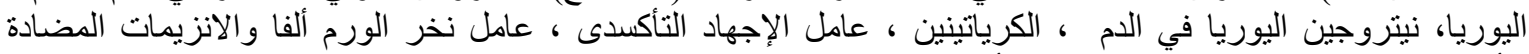
للأكسدة قد تم تقييمهم والتشريح المرضيا في لإمي للأنسجة الكلوية.

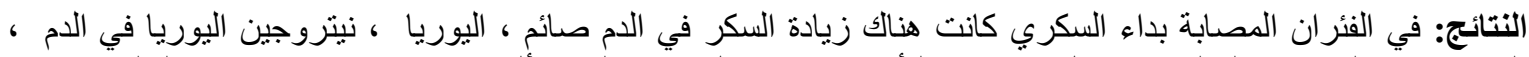

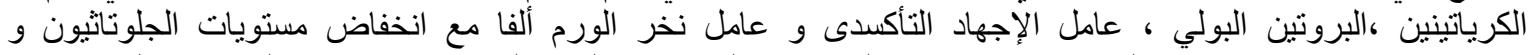

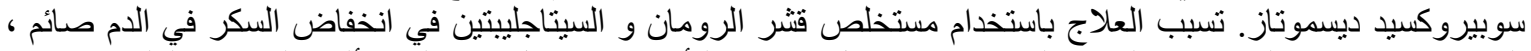

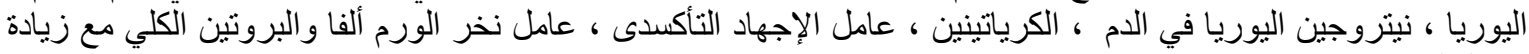

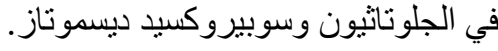

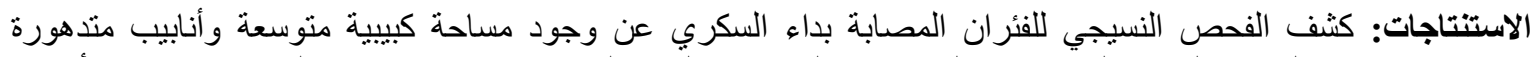

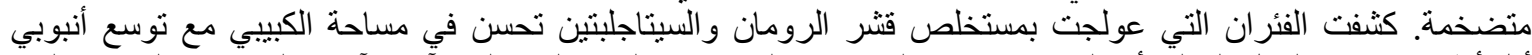

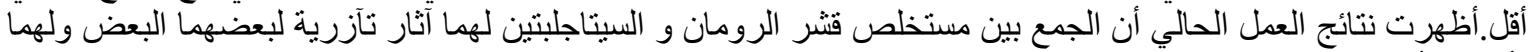
تأثير ات أفضل على الكلي في الفئران المصابة بداء السكري.

الكلمات المفتاحية: مضادات الأكسدة, فلافونيدات, حماية الكلي, نيكوتيناميد, استربتوزوتوسين.

الأبحم: حنان عضئم محم ـ قسم الفسيولولجى كلية الطب ، بنات، القاهرة ، جامعة الأزهر ، جمهورية مصر العربية

01274804838 : البهاتف

hanan.essam@med.helwan.edu.eg : البريد الإكتروني: 